Research.

\title{
THE IMPACT OF THE UNPAYABLE ACCOUNTS RECEIVABLE ON THE LIQUIDITY LEVEL AT PT ABC
}

\author{
Syarief Gerald Prasetya \\ Lecturer at STIE Binaniaga, Bogor
}

\begin{abstract}
The capability of a company to settle down its short-term liabilities has been one factor to determine whether the financial of a company is good or not. This kind of capability is the liquidity level. One factor that has determined the company's liquidity level whether it is huge or small one is depending on the total of the accounts receivable owned by the company. The method of this research has applied the associative descriptive method describing the connection of two or more variables. To identify the liquidity level of the company, it has been applying a proxy analysis of liquidity ratio. Identifying the impact of the unpayable accounts receivable on the liquidity level has been applying a simple regression equation. The test result using $t$-test has indicated a significant effect. Moreover, it has been noticed that the amount of unpayable account receivables has been determining the liquidity level of the company. The suggestion to increase the liquidity level is by reducing the total amount of current liabilities.
\end{abstract}

Keywords: bad debt, liquidity, account receivable

\section{INTRODUCTION}

Getting the finance support is absolutely required by the company, actually the most important factor to make a company exists at any kind of economics condition is the effort of the company to manage its finance. Finance management is very crucial, since eventhough the company has had a huge amount of the money, but it would jeopardize the company if it had not been managed very well. But on the contrary, eventhough the company has had a limited financing, however if it had been managed properly, the company would be developing and getting much profit. Having had a huge profit, financing resources could be collected within the internal company itself.

The company's finance management is how the company is able to pay its shortterm liabilities.. It means that the company has been in a good health since it has been able financing all its daily operational activity and to settle down its short-term liabilities which have been due date. It is very important as the company will need the money to operate its daily activities. So that when the company has had enough financing to produce the products and services, it will get the revenue and profit absolutely.

The capability level of the company which is able to settle down all its short-term liabilities has been one of the important factor whether the company is considered to have a good finance or not. This capability is named liquidity level, And the factor which can identify the liquidity level of the company is the total amount of its accounts receivable. In general, the bigger accounts receivable of the company has had, the highest liquidity level of the company will be. However, as a matter of fact, a part of the accounts receivable of the company can not be collected. So that, it will affect the liquidity level of the company obviously. Based on the aforementioned description, the problems to be studied on this research are as follows; Has any impact of the unpayable accounts receivable on the liquidity level of PT ABC occurred during the period of 2010 up to 
2015?. Hence, the hypothesis of this research is that the impact of the unpayable or uncollected accounts receivable on the liquidity level has happened accordingly.

\section{THEORY REVIEW}

\section{A. Liquidity description}

The company's liquidity is related to the capability of the company which can pay all its short-term liabilities. The total of a company's assets is considered as the power of the company to execute any payment required. However, though the company has had such the capability to provide the payment, but it might be unable to settle down all its financial liabilities required, or, on the other words, it might be unable to pay all the liabilities required.

A company that is having the power to pay all its financial liabilities is a liquid company, but, a company which is not having such the power to pay all its financial liabilities is illiquid. When such the ability providing the payment is related to the debts to the third party or creditor, it is the liquidity of an enterprise. So that, it means the capability of the company providing much liquid assets to be able to pay all the financial liabilities required on due date. However, when the ability to provide such the payment is related to the financial liability to execute the daily production process of the company, it is the company's liquidity. Liquidity ratio is consisting of Current Ratio and Quick Ratio (Acid Test Ratio)

$\begin{aligned} \text { Current Ratio } & =\frac{\text { Current Assets }}{\text { Current liabilities }} \\ \text { Quick Ratio (Acid Test Ratio) } & =\frac{\text { Current Assets - Inventory }}{\text { current liabilities }}\end{aligned}$

It could be said that the companies which are having the current ratio less than $2: 1$, they are considered not in a good condition because when their current assets are decreasing to more than $50 \%$, their current assets will not be sufficient covering all their current liabilities (Riyanto, 1998 : 18). However, this guideline is only based on a secure principle, so that, the guideline of current ratio $200 \%$ is not an absolute one. It means that each company should have to understand the maximum amount of the short-term credit that can be used in order to avoid any violation of the current ratio guideline. Nevertheless, when the company has decided the current ratio 3:1 or $300 \%$, it explains that each 1 figure of current liability should have been guaranteed by the current assets of 3 (three).

Calculating this liquidity has usually applied quick ratio method or acid test ratio, total current assets is not taken away completely, but only a part of it which is considered having a high level of the liquidity refers to cash, stocks and accounts receivables. So that, by applying this method, the company which is having the level of quick ratio of $1: 1$ or $100 \%$ is considered not in a good condition refers to its liquidity level.

\section{B. Accounts receivables description}

Accounts receivable is an account recorded on the finance report of the company. Accounts receivable is an important element of the company since it is the current assets related closely to the sales of goods or services done by the company. Accounts receivable can be related to the accounts payable to the employees, down payment of the purchasing and selling the current assets. However, the accounts 
receivable has come up when selling the goods or services by credit term has done which is trading credits. This kind or trading credits is an important element that should have to be well managed by the management to avoid any company liquidity losses.

Accounts receivable has been a continuous turnover of working capital; Cash $>$ Inventory $->$ Accounts receivable $->$ Cash. In a normal condition when the sales has been done based on the credit terms, the accounts receivable has been indicating that the liquidity aspect is higher than the inventory.

In connection with the accounts receivable refers to the accounting principles, an accounts receivable is defined by the total bruto of accounts receivable minus the anticipatory total of unpayable accounts receivable.

\section{Uncertain accounts receivable description.}

An uncertain accounts receivable is an anticipatory unpayable account receivable. Value of the tariff of uncertain accounts receivable is calculated by the management considering some certain issues that are supporting the most rational decisions. In connection with the finance report of uncertain accounts receivable, it is reported as the Losses of Accounts Receivable and the Reserve accounts receivable losses. Recording method of uncertain accounts receivable is as follows;

This method has applied an anticipatory total losses of accounts receivable at the end of the period which will be calculated within the related periode. It is an anticipatory accounts receivable that cannot be paid by the customers. Furthermore, the related total amount will be recorded on the following journal.

Accounts receivable losses Rp $x x x \cdot x x x, x x$

Total reserves of the accounts receivable losses

$\operatorname{Rp} x x x . x x x, x x$

The total amount of the related uncertain accounts receivable will be determined according to the actual amount of the unpayable accounts receivable. The determination of the total is based on the data regarding the condition of the debitor, eq; the debitor has not paid yet for such a long time; has had a liquidity problems; bankcrupt or death, etc. Such the total amount will be considered as the losses of accounts receivable eliminated which is recoded on the journal as follows;

Reserve of account receivable losses Rp $x x x \cdot x x x, x x$

Account receivable $\operatorname{Rp} x x x \cdot x x x, x x$

Sometimes the unpyable account receivable which has been noted as uncollected payment, but actually, the debitor could pay it, therefore, the journal of account receivable will be as follows:

Cash Rp $\quad X X . X X X, X X$

Reserve account receivable losses...... Rp $x x . x x x, x x$

\section{The impact of unpayable accounts receivable on the liquidity level.}

Account receivable collectability has been influenced a lot by the vendor capacity which is the external party, so that, the company as the creditor has not been affecting the collectability level of accounts receivable properly. Preparing the report which is related to the financial capacity is required a certain matter describing that the value will be the actual value of the assets. In order to notice the connection between the accounts receivable and the liquidity level, the writer will illustrate it as follows: 


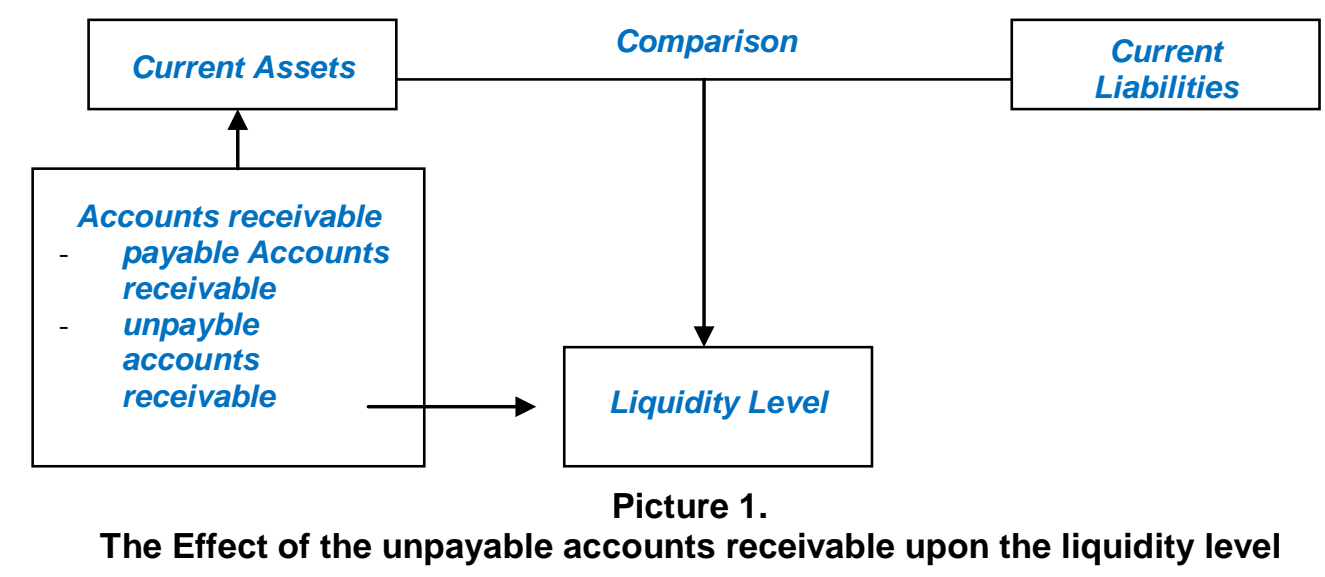

Based on the aforementioned drawing, it explains that the value of accounts receivable is not the real value, it is an abstract one. The value of the related accounts receivable is owned by the company, but, the company cannot use it as much as possible, because it is not cash. Though, such the value of accounts receivable can be traded, but not all the transaction causing debts and credits can be treated just like it. In order to define the real value of accounts receivable as the assets, the total value of the accounts receivable should have to erased, so that the net value of accounts receivable can be achieved and it has had a logic assumption which is the related net value of accounts receivable that can be collected. On the other words, the related accounts receivable is the maximum collectivability level.

When the related accounts receivable has been eliminated, it explains that a reducing value of the accounts receivable has happened and it can be determined as an unpayable value of the accounts receivable. The uncertain collectivibility of reducing value of the accounts receivable will be in accordance with the tariffs determined by a specific policy of the management to ensure how much amount of the accounts receivable can be collected. The value of the accounts receivable that can not be collected will affect the big value of current assets of the company. However, it can be defined that the unpayable accounts receivable will affect the reducing value of the current assets.

As noticed that the liquidity level has been determined by comparing the ratio of current assets and current liabilities. When the value of current assets is big, then the liquidity level of the company is also big. On the contrary, when the value of current assets is small, then the liquidity level of the company is also small. According to the aforementioned description, it has explained that the value of unpayable accounts receivable will affect the value of the current assets of the company. When the unpayable accounts receivable is bigger, the value of current assets of the company is smaller which is at the end it will make the liquidity level small. However, it can be figured out that unpayable accounts receivable has had a connection and indirect effect with the liquidity level of the company.

\section{RESEARCH METHOD}

\section{A. The Definition of the Operational Variable} follows;

Some variables that will be applied within this research will be defined as

1. Accounts receivable is an accounts of current assets happened due to the selling activities of products or services done by the company to the customer using a credit term. 
2. Unpayable accounts receivable is the value of accounts receivable that can not be collected by the company due to the particular reasons.

3. Liquidity level has indicated the ability of the company to settle down its short term liabilities (including daily operational of the company and the effort to pay the current liabilities which has been due-date).

\section{B. The Research Method}

Method of the research has applied an associative descriptive method in order to figure out the connection of two or more variables identified. Applying the associative descriptive method is describing the effect of the changes of unpayable accounts receivable upon the changes of company liquidity level.

\section{Data Collecting Technique}

Due to the data analysis requirement and description, this research has collected the data using the following ways:

\section{Primary Data}

Primary data are the data obtained directly from the objects being studied. In order to obtain such the data, the writer has done field research which is the data collection as the following; Observation, is a data collection technique using a direct observation at the research place. The writer had conducted the observation regarding the procedures and the system of the finance accountancy recording done by the company.

\section{Secondary Data}

Secondary data are the data obtained from the records or information of various resources. In order to get such the data, the writer has conducted the library research refers to the study and record the reports or information of the company (such as, financial report, company's profile, etc).

\section{Data Analysis Technique}

Data analysis has applied some following techniques;

1. Identifying the company liquidity level has applied a proxy analysis of liquidity ratio refers to Current Ratio as follows (Riyanto, $2000: 18)$ :

Descriptions:

$$
C R=\frac{\mathrm{AL}}{\mathrm{UL}}
$$

$$
\begin{array}{lll}
\mathrm{CR} & =\text { liquidity level } \\
\mathrm{AL} & =\text { Current Assets } \\
\mathrm{UL} & =\text { Current Liabilities }
\end{array}
$$

2. Identifying the effect of unpayable accounts receivable upon the liquidity level has applied a simple regression equation, as follows (Mulyono, $1991: 202$ ):

$$
\begin{array}{rll}
\text { Descriptions } & & \mathrm{LK}=\alpha+\beta \mathrm{PT}+\varepsilon \\
\text { LK } & = & \text { Liquidity proxy } \\
\text { PT } & = & \text { Unpayable accounts receivable (bad debts) } \\
\beta & = & \text { regression coefficient } \\
\alpha & =\text { constant } \\
\varepsilon & =\text { error }
\end{array}
$$


Furthermore, to figure out whether the unpayable accounts receivable has affected the liquidity level, t-test has been applied using the following equation;

Description

$$
t=r \sqrt{\frac{n-2}{1-r^{2}}}
$$

$\mathrm{t}=$ the value of $\mathrm{t}$-calculated

$r=$ the correlation coefficient

$\mathrm{n}=$ Total of the samples

$r^{2}=$ the determinant coefficient

The test has done a single direction using the significant level of $5 \%$ and independent degree $(n-2)$. Morever the value of $t_{\text {calculated }}$ will be compared with the value of $t_{\text {table }}$ according to the following criteria:

- when the value of $t_{\text {calculated }}$ is bigger than $t_{\text {table }}\left(t_{\text {calculated }}>t_{\text {table }}\right)$, then $H_{0}$ hypothesis will be accepted.

- When the value of $t_{\text {calculated }}$ is smaller than $t_{\text {table }}\left(t_{\text {calculated }}<t_{\text {table }}\right)$, then $H_{0}$ hypothesis is rejected.

When $\mathrm{H}_{\mathrm{o}}$ hypothesis is accepted, it explains that there is not any significant effect of unpyable accounts receivable happened upon the liquidity level.

\section{ANALYSIS AND THE DESCRIPTION}

The achievable liquidity level of the company has identified the condition or the performance of the related company whether it is good or bad. This liquidity level will affect other cost accounts mentioned on the current assets and current liabilities. Current assets and current liabilities can be identified on the balance sheet of the company. Therefore, the company should have to prepare the balance sheets properly since it will indicate the liquidity level of the company being achieved.

Referring to the result of analysis regarding the liquidity level achieved by PT ABC within 2010 up to 2015, it can be concluded that PT ABC has paid its current liabilities using its current assets. It has indicated that during the year of 2010 up to 2015, PT ABC can afford to finance the company daily operational activities. Nevertheless, its liquidity level has not reached yet the good standard. It has been identified that the liquidity level achieved by the company within the year of 2010 to 2015 is still below 2 (two).

Theoretically it is noticed that one of the posts that has been affecting the liquidity level achieved by the company is depending on the total amount of the accounts receivable that can be collected successfully by the related company. The accounts receivable itself has been classified into two categories, one category is the accounts receivable that can be collected or paid and the other one can not be collected. In order to figure out the comparison between the liquidity level achieved by PT ABC and the total amount of the unpayable accounts receivable will be described on the following table;

Table 1

Total amount of the unpayable accounts receivable and the liquidity level of PT ABC in 2010 up to 2015

\begin{tabular}{|c|c|r|r|}
\hline \multirow{2}{*}{ Year } & Semester & $\begin{array}{c}\text { Unpayable Accounts } \\
\text { (in billion rupiah) }\end{array}$ & $\begin{array}{c}\text { Liquidity } \\
\text { Level }\end{array}$ \\
\hline \multirow{2}{*}{2010} & $\mathrm{I}$ & $3,553.058$ & 1,79 \\
\cline { 2 - 4 } & $\mathrm{II}$ & $3,042.650$ & 1,87 \\
\hline \multirow{2}{*}{2003} & $\mathrm{I}$ & $2,983.388$ & 1,91 \\
\cline { 2 - 4 } & $\mathrm{II}$ & $3,258.700$ & 1,73 \\
\hline
\end{tabular}

Syarief Gerald Prasetya: The Impact of The Unpayable Accounts Receivable on The Liquidity Level at PT ABC 


\begin{tabular}{|c|c|r|r|}
\hline Year & Semester & $\begin{array}{c}\text { Unpayable Accounts } \\
\text { (in billion rupiah) }\end{array}$ & $\begin{array}{c}\text { Liquidity } \\
\text { Level }\end{array}$ \\
\hline \multirow{2}{*}{2004} & $\mathrm{I}$ & $3,797.929$ & 1,61 \\
\cline { 2 - 4 } & $\mathrm{II}$ & $3,168.790$ & 1,81 \\
\hline \multirow{2}{*}{2005} & $\mathrm{I}$ & $2,935.802$ & 1,83 \\
\cline { 2 - 4 } & $\mathrm{II}$ & $3,245.800$ & 1,72 \\
\hline \multirow{2}{*}{2006} & $\mathrm{I}$ & $2,356.809$ & 1,97 \\
\cline { 2 - 4 } & $\mathrm{II}$ & $2,587.600$ & 1,78 \\
\hline \multirow{2}{*}{2015} & $\mathrm{I}$ & $2,693.496$ & 1,72 \\
\cline { 2 - 5 } & $\mathrm{II}$ & $3,157.850$ & 1.71 \\
\hline \multicolumn{2}{|c|}{ Total } & $36,781.872$ & 21,45 \\
\hline \multicolumn{2}{|c|}{ Average } & $3,065.156$ & 1,79 \\
\hline
\end{tabular}

Sources: data analyzed

Based on the aforementioned table, it explains that during the year of 2010 up to 2015 , the total amount of unpayable accounts receivable of PT ABC has been fluctuated accordingly per semester. As a matter of fact the total amount of unpayable accounts receivable during the research has been Rp. 3,065,156,000.- per semester.

To clarify the fluctuation of the amount of the unpayable accounts receivable will be described on the following drawing:

\section{Unpayable accounts receivable in billion rupiah}

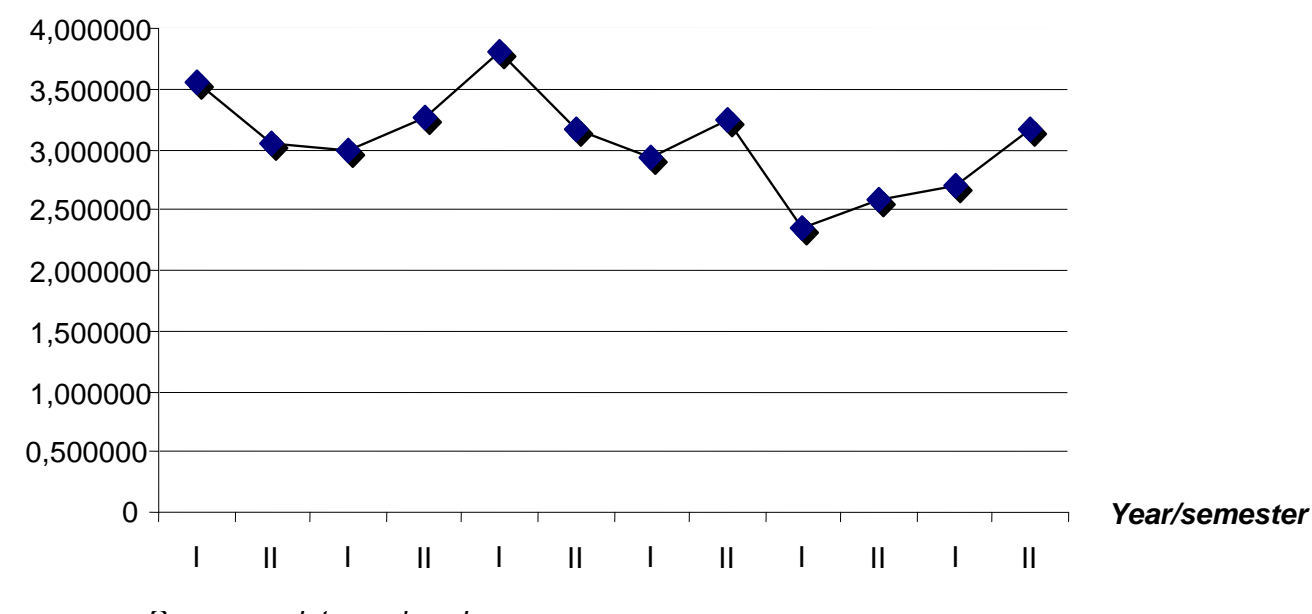

Sources : data analyzed

Drawing 2

Total amount of the unpayable accounts receivable of PT ABC for the period of 2010 to 2015

The aforementioned drawing has explained that the total amount of the unpayable accounts receivable of PT ABC for the years of 2019 up top 2015 has been fluctuating which is up and down each semester. Nevertheless, overall the total amount of the unpayable accounts receivable per semester has been about $R p 2,000,000,000$.- up to

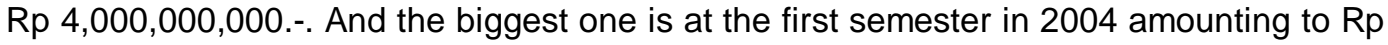
$3,797,929,000$.- indicated on the graph which is at the top one compared with others. However, the smallest amount of the unpayable accounts receivable is at the semeser 1 
in 2006 amounting to $\operatorname{Rp} 2,356,809,000$.- which is indicated at the lowest point on the graph.

The aforementioned table 1 (one) has indicated that the liquidity level achieved by PT ABC for the period of 2010 up to 2015 has been fluctuating each semester accordingly. On average the liquidity level has achieved 1.79 / semester. The fluctuation of the liquidity level has been indicated on the following drawing;

Tingkat Likuiditas Liquidity Level

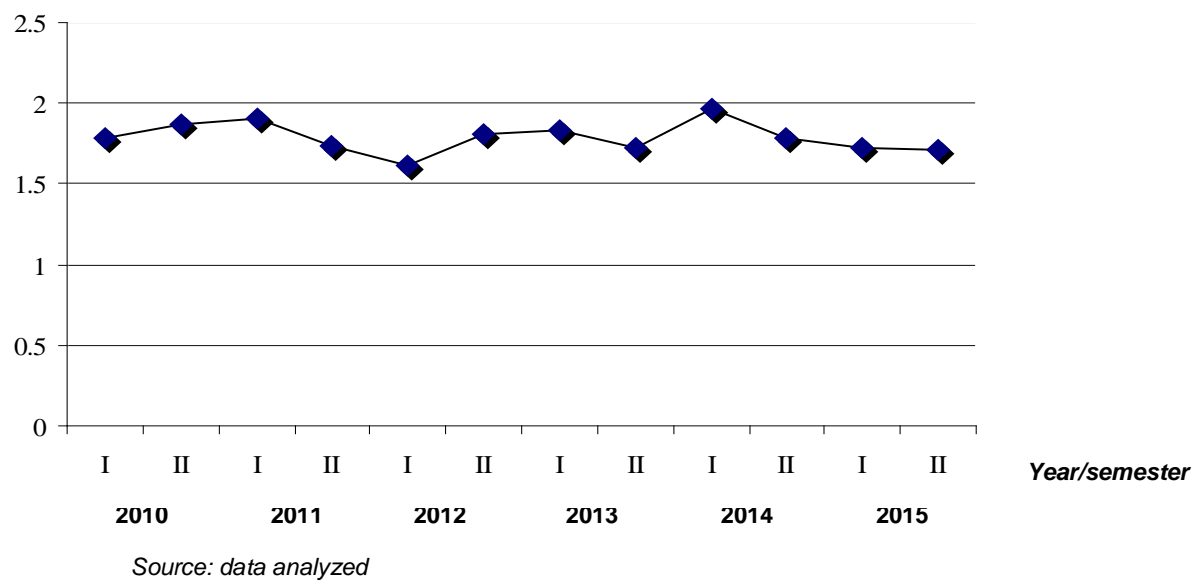

Source: data analyzed

\section{Drawing 3}

Liquidity Level of PT ABC during 2010 up to 2015

As well as the total of unpayable accounts receivable, the liquidity level of PT ABC during 2010 up to 2015 / semester has been fluctating accordingly (up and down sometimes). The fluctuation of the liquidity level is about 1.50 up to 2.00 . The highest level the liquidity has happened on the semester 1 (one) in 2006 which is indicated on the graph refers to the highest one of 1.97. Nevertheless, the lowest level of the liquidity has happened on the semester 1 (one) in 2004 which is 1.61 indicated on the graph at the lowest one comparing with others.

Furthermore, an analysis about the effect of unpayable accounts receivable upon the liquidity level of PT ABC has indicated the correlation coefficient of $r$ which is -0.633 (negative value). This kind of value has interpreted that the correlation between the unpayable accounts receivable and the liquidity level is 0.633 and has been a negative correlation or opposite. The correlation between the unpayable accounts receivable and the liquidity level has determined a strong correlationThis kind or correlation is negative or opposite correlation, it means that when an increasing of unpayable accounts receivable has occurred, the value of the liquidity level has decreased, on the contrary, when a decreasing value of unpayable accounts receivable has happened, the liquidity level will increase obviously. According to the aforementioned description, it can be concluded that the correlation between the unpayable accounts receivable and the liquidity level of PT ABS is strong but negative.

Furthermore, in order to figure out the contribution of the unpayable accounts receivable which has affected the liquidity level achieved by PT ABC, the calculation of determinant coefficient (KD) has been conducted and the results are as follows;

$$
\begin{aligned}
& \mathrm{KD}=(0,633)^{2} \cdot 100 \% \\
& \mathrm{KD}=0.4007 \cdot 100 \% \\
& \mathrm{KD}=40,07 \%
\end{aligned}
$$


The calculation has given the value of determinant coefficient (KD) of $40.07 \%$. This KD value has explained that the unpayable accounts receivable has determined the liquidity level of $40.07 \%$ or on the other words the value of unpayable accounts receivable has affected $40.07 \%$ of the liquidity level achieved by PT ABC and the remaining of $59.93 \%$ has been affected by other variables such as, the value of cash receivable, equipments, accounts receivable, downpayment, business debts and other liabilities

Referring to the result of the calculation, it has identified the constanta $(\alpha)$ value of 2.266 and coefficient (b) value of -0.000000156 . These value have produced a simple linear regression equation LK $=2.266-0.000000156 \mathrm{PT}$. The constanta $(\alpha)$ value of 2.266 has indicated that if there were not any unpayable accounts receivable occured, the liquidity level of 2.266 of PT ABC could be achieved. Based on the related matters, it has noted that if the unpayable accounts receivable were not available at one period, the liquidity level of 2.266 could be achievable.

This analysis has indicated that eventhough there is not any unpayable accounts receivable available, but the achievable liquidity level has beent in a good category which is it has had a comparison of more than 2 (two) figure. It has been indicated that the unpayable accounts receivable will determine the liquidity level being achieved whether it is big or small. This analysis has complied with the determinant coefficient (KD) analysis mentioning that the variable of the unpayable accounts receivable has determined obviously the liquidity level of $40.07 \%$ that has been achieved by PT ABC.

Coefficient $(\beta)$ value of -0.000000156 has explained that when an increasing value of Rp 1 (one) the unpayable accounts receivable has happened, but with the assumption that other fixed variables have also been affecting it, however, the liquidity level achieved by PT ABC will be decreasing for about 0.000000156 . Or it can be defined that when the value of unpayable accounts receivable has increased $R p 1,000,000,-$, the liquidity level would decrease 0.156 .

It is noticable that the negative value of the coefficient is in compliance with the result of the analysis of the correlation ( $r$ ) which is having a negative or opposite correlation. Therefore, it can be defined that the unpayable accounts receivable has connected and affected negatively the liquidity level achieved by PT ABC

Furthermore, to figure out a significant effect of the unpayable accounts receivable upon the liquidity level, t-test should have to be done. The calculation has resulted the value of $t_{\text {calculated }}$ which is -2.585 . Moreover, the value of $t_{\text {table }}$ of -1.81 has been obtained. Based on the comparison among such the aforementioned value, it has indicated that the value of $t_{\text {calculated }}$ is smaller than the value of $t_{\text {table }}(-2.585<-1.81)$. To clarify this test, the following drawing will describe it completely:

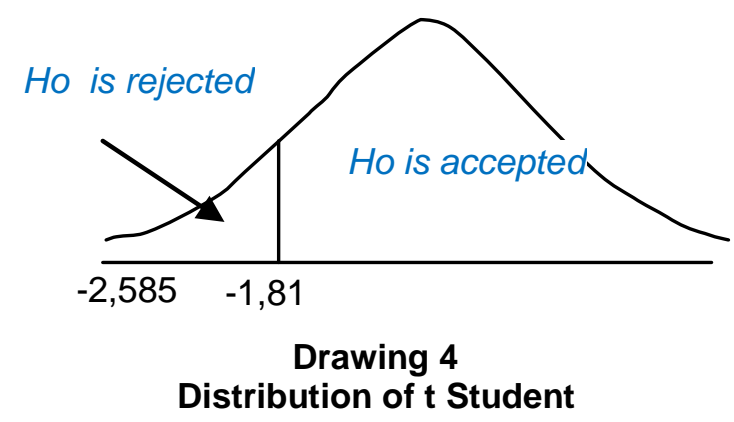

Syarief Gerald Prasetya: The Impact of The Unpayable Accounts Receivable on The Liquidity Level at PT ABC 
Based on the aforementionned drawing, it is indicating that the value of $t_{\text {calculated }}$ is on the left $t_{\text {table }}$ value. However, the value of $t_{\text {calculated }}$ is smaller than the value of $t_{\text {table }}$, it explains that the result of this research has rejected the hypothesis of $\mathrm{H}_{0}$ and accepted the hypothesis of $\mathrm{H}_{\mathrm{a}}$. Therefore, it can be defined that the unpayable accounts receivable has affected significantly the liquidity level achieved by PT ABC.

\section{CONCLUSION AND SUGGESTIONS}

\section{A. Conclusion}

Based on the aforementioned result of analysis, it can be concluded that during the period of 2010 to 2015 the liquidity level that has been achieved by PT $A B C$ is good. Because during that period the company is able to cover all its shortterm liabilities refers to the current liabilities payment and daily operational activities cost. However, overall the liquidity level achieved by PT ABC has not yet encountered a good standard of liquidity level which is 2 (two) during the related period.

It is noticed that the liquidity level has been fluctuating during the year of 2010 - 2015 because of the big amount of the unpayable accounts receivable has occurred. Based on the result of the data analysis, the unpayable accounts receivable has significantly affected the liquidity level achieved by PT ABC. This result has been identified by t-test application. Moreover, the amount of unpayable accounts receivable has contributed $40.07 \%$ to determine the liquidity level of the company, but the rest has been contributed by other factors which are cash, equipment, current accounts receivable and liabilities.

\section{B. Suggestions}

Referring to the result of analysis and the conclusion of this research, the writer has offered some suggestions that are expected to be usefull for PT ABC to improve the company financial performance. The suggestions are as follows:

1. $P T A B C$ should have increased more the liquidity level of the company since PT ABC liquidity level has not yet been considered good. The strategy to increase the liquidity level is to reduce the total amount of the company current liabilities.

2. Since the effect of the unpayable accounts receivable upon the liquidity level of the company is very important, PT ABC should have managed the company accounts receivable more carefully. Because, the more the unpayable accounts receivable happened, the more decreasing of liquidity level achieved by the company occured.

3. It is advisable to perform further research regarding some factors that could affect either big or small liquidity level achieved by the company.

\section{REFERENCES}

Baridwan Z. Intermediate Accounting Edisi Ketujuh. Penerbit BPFE UGM, Jogjakarta. 1997.

Fess, et. all. Accounting $\mathbf{8}^{\text {th }}$ Edition. South Western College Publishing. 1995.

Harahap S, S. Analisa Kritis Atas Laporan Keuangan Edisi Satu. Penerbit Raja Grafindo Persada, Jakarta. 1998.

Helfert. Technique of Financial Analysis, Terjemahan Herman Wibowo, Analsis Laporan Keuangan Edisi Ketujuh. Penerbit Erlangga, Jakarta. 1993. 
Ikatan Akuntan Indonesia. Standar Akuntansi Keuangan Buku Satu. Penerbit Salemba Empat, Jakarta. 1995.

Kerlinger F. dan Phedazur, (1987), Korelasi dan Analisa Regresi Ganda, Nurcahya.

Mulyono, S. Statistika Untuk Ekonomi. Lembaga Penerbit Fakultas Ekonomi Universitas Indonesia. Jakarta, 1991.

Munawir. Analisa Laporan Keuangan Edisi Empat. Penerbit Liberty, Jogjakarta. 1990.

Nawawi, H. Metode Penelitian Bidang Sosial. University Press, Jogjakarta. 1998.

Riyanto, B. Dasar-Dasar Pembelanjaan Perusahaan. Edisi Keempat, Yayasan Penerbit Gajah Mada, Jogyakarta. 1998.

Sartono ,A,R. Manajemen Keuangan : Teori dan Aplikasi. BPFE, Jogjakarta. 2000.

Soeprihanto J dan Sumarni M. Pengantar Bisnis : Dasar-Dasar Ekonomi Perusahaan Edisi Kelima. Liberty. Jogjakarta. 1998

Sundjaja RS dan Barlian I. Manajemen Keuangan Satu Edisi Keempat. PT. Prenhallindo, Jakarta. 2010.

Sugiyono, Metode Penelitian Administrasi, Alfa Beta, Bandung, 2001. 
The Accounting Journal of BINANIAGA Vol. 02, No. 02, December 2017

PISSN: $2527-4309$

EISSN: $2580-1481$

This page intentionally be emptied.

Syarief Gerald Prasetya: The Impact of The Unpayable Accounts Receivable on The Liquidity Level at PT ABC

Page : 22 